\title{
Potential Enrichment of Scandium in Bauxite Deposit for the Emerging Green Technology Needs
}

\author{
Adinda Ramadhani Haka Putri ${ }^{{ }^{*}}$, Lucas Donny Setijadji ${ }^{1,}$, Dedi Sunjaya ${ }^{2}$ \\ ${ }^{1}$ Department of Geological Engineering, Faculty of Engineering, \\ Universitas Gadjah Mada, Yogyakarta, Indonesia \\ ${ }^{2} \mathrm{PT}$. Aneka Tambang Tbk, Jakarta, Indonesia \\ *Corresponding author: adinda.r@ mail.ugm.ac.id
}

Article received: 4 December 2020, revised:15 April 2021, accepted: 20 August 2021

DOI: $10.51835 /$ ijeg.2021.1.1.343

\begin{abstract}
Scandium (Sc) becomes one of critical raw materials as principal uses are now in the production of scandium-aluminum alloys and also in Solid Oxide Fuel Cells (SOFCs). Scarcity of scandium resources has led the urgency to discover new potential sources of scandium to meet the supply and demand. One of the possible sources of scandium is from bauxite deposit. Tayan area is part of West Kalimantan laterite belt with the potency for scandium resources in Indonesia as a result of the altered granitoid rocks, namely bauxite. This study presents integrated geological and modes of occurrences study to elucidate the potential enrichment of scandium in the study area including through several laboratory analyses: petrography, XRD, XRF, ICP-MS, and SEM-BSE-EDS. Our study concludes that the concretion textures of bauxite samples are dominated by $\mathrm{Fe}$ and $\mathrm{Al}$ oxide-hydroxide. The ore is composed of gibbsite and goethite. The result of scandium concentration analysis is equal to $50.9 \mathrm{ppm}$. Systematic SEM-EDS mapping confirms the presence of scandium as mainly from substitution of $\mathrm{Fe}^{3+}$ and $\mathrm{Al}^{3+}$ by $\mathrm{Sc}^{3+}$. $\mathrm{Sc}$ is hosted in goethite, where $\mathrm{Sc}^{3+}$ substitutes $\mathrm{Fe}^{3+}$ in goethite crystal lattice. $\mathrm{Sc}^{3+}$ also substitutes $\mathrm{Al}^{3+}$ in gibbsite crystal lattice. Understanding the enrichment in which scandium occurs in bauxite deposit will hopefully open the new possibility to meet the needs for critical materials for green technology development.
\end{abstract}

Keywords: Scandium, bauxite deposit, green technology

\section{INTRODUCTION}

According to International Union of Pure and Applied Chemistry (IUPAC), scandium is classified as REE as it is found along with other 15 REE elements in the lanthanide group plus yttrium (Zhou et al., 2017). Scandium (Sc) is an important element since it becomes one of critical raw materials (CRM). Raw materials were identified as critical by 3 key findings assessments: (1) there are no viable substitute materials using current production technologies, (2) most consumer countries are dependent on importing, and (3) its supply is dominated of only one or few producers (European Commission, 2017 in Swamidharma, 2020).
Raw materials play important role to support some development of emerging innovations. Based on economic importance and supply risks parameters, in 2017 scandium is classed as CRM by European Commission. Scandium's two most promising applications are now in scandiumaluminum alloys and in Solid Oxide Fuel Cells (SOFCs). A small amount of scandium $(0.35-0.4 \%$ Sc) can alloy aluminum base materials (Maulana et al., 2019). This type of alloy has number of benefits including light, strong, good heat tolerance, and weldability. The primary applications of Al-Sc alloys can be used in sport equipment and air transportation industry. Meanwhile, SOFCs are a major application of scandium. Scandia 
$\left(\mathrm{Sc}_{2} \mathrm{O}_{3}\right)$ as the stabilizing agent for the zirconia $\left(\mathrm{ZrO}_{2}\right)$ is an excellent option for using as a high efficiency electrolyte in solid oxide fuel cells. Many companies use several types of fuel cells, but solid oxide fuel cells are currently the best in terms of costefficiency, flexibility, electricity conductor, and low pollution. Therefore, scandium is one of the most valuable elements and the demand is driven by energy issues.

In that regard, physically, scandium is silvery metallic and a soft element. Chemically, scandium has atomic number 21, making it the lightest of the transition metals. In fact, like other rare earth elements, scandium as a part of transition metal is more abundant compared to common elements such as lead, mercury, and all the precious metals. Scandium is not quite rare on the surface of the earth and can be found in small concentrations as exist in an oxide form $\left(\mathrm{Sc}_{2} \mathrm{O}_{3}\right)$.

Most of today's scandium production will in general come as a by-product of refining activity related with metals and minerals, explicitly mill tailings of $\mathrm{U}, \mathrm{Th}, \mathrm{Al}$, $\mathrm{W}, \mathrm{Sn}, \mathrm{Ta}, \mathrm{P}$ and REE (Duyvesteyn and Putnam, 2014). New report suggests potentially significant scandium resource is in red mud tailings from Bayer process, which employed bauxite processing into alumina. A concern on red mud tailing developed over bauxite deposit where concentration of scandium is up to 50-110 ppm (Duyvesteyn and Putnam, 2014). Based on Shaoquan and Suqing (1996), ores with a scandium content range between $20-50 \mathrm{ppm}$ are considered as resources and feasible of exploitation. Scarcity of scandium resources has led the urgency to discover new potential sources. One of the possible sources is from bauxite laterite deposit. Bauxite have attracted much attention as a promising elective scandium resource.

Tayan mine is the most important location for bauxite deposits in Indonesia. The area is part of West Kalimantan laterite belt (Figure 1) with the potency for scandium resources. Bauxite occurs as a result of the altered granitoid intrusive rocks. From the recent investigation, scandium and others REE element can be extracted from weathering of the minerals of bauxite's precursor rocks by mobilization, distribution, and fractionation during lateritization (Sunjaya et al., 2019a).

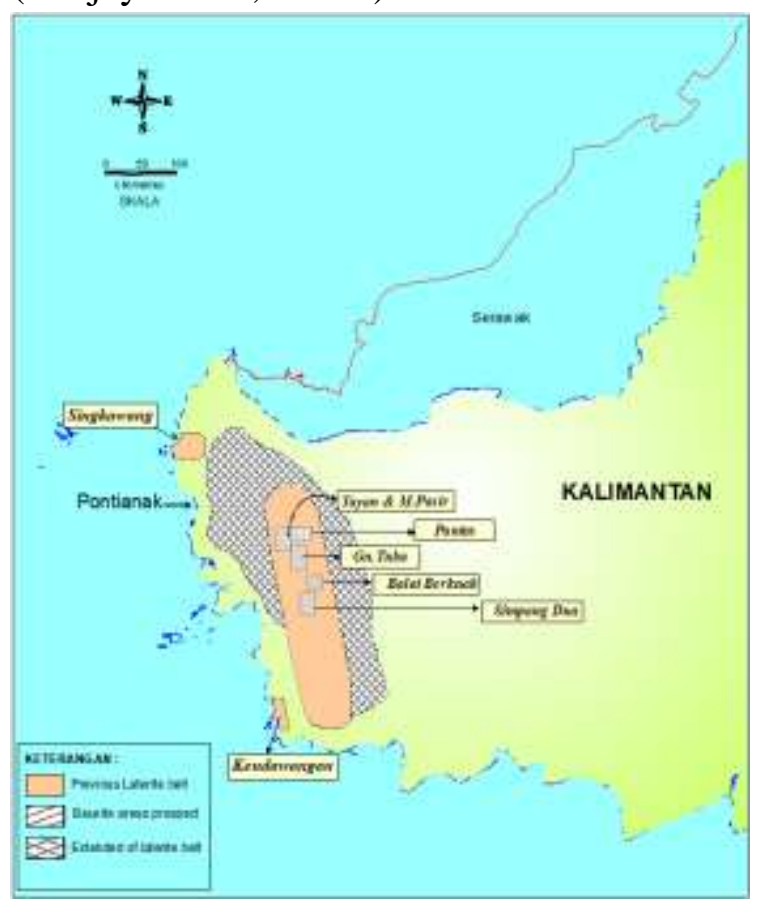

Figure 1. Bauxite laterite belts in West Kalimantan (Surata et al., 2010).

The term bauxite is generally defined as weathering products of rocks rich in alumina, but low in alkalis, alkaline earths, and silica (Valeton, 1972). Geologically, bauxite deposit in Indonesia is lateritic type which associate with igneous rocks that are rich in aluminum silicate minerals and supported by the tropical to subtropical climates (Hindarto et al., 2019). 
The geology of laterite bauxite deposit is classified into three zones from top to bottom, namely: latosol, bauxite, and kong / pallid (Sunjaya et al., 2019b). The three zones are represented in Figure 2, including: (1) Latosol zone (laterit paleosol), is the topmost section of the bauxite laterite profile with high levels of $\mathrm{SiO}_{2}$, but low of $\mathrm{Fe}_{2} \mathrm{O}_{3}$ and $\mathrm{Al}_{2} \mathrm{O}_{3}$. (2) Bauxite zone characterized by presence of concretions in size from sand to boulder (2 $>256 \mathrm{~mm}$ ). Composed with abundant Al2O3, but low $\mathrm{SiO}_{2}$ and $\mathrm{Fe}_{2} \mathrm{O}_{3}$ (3) Kong zone dominated by clay-sized material with white to reddish brown appearance.

Based on Lavrenchuk et al., (2004, in Vind et al., 2018), it is estimated that $70 \%$ of the world's scandium resources can be found in bauxite deposits. It is because scandium as a lithophile element is not easily transformed under oxidized environmental conditions. In general, rare earth elements properties in nature are trivalent $\left(\mathrm{Ln}^{3+}\right)$. Thus, during the weathering process of the parent rock, $\mathrm{Sc}^{3+}$ will be released from its parent minerals and easily substitute for other elements that are equivalent such as $\mathrm{Al}^{3+}$ and $\mathrm{Fe}^{3+}$. To illustrate, the substitution of $\mathrm{Sc}^{3+}$ for $\mathrm{Fe}^{3+}$ is easier than for $\mathrm{Al}^{3+}$ (Horovitz et al., 1975). This similarity in trivalent chemical properties indicates that rare earth elements can substitute each other in their crystal structure (Walters and Lusty, 2011).

There is still lack of published data discussing scandium in bauxite deposit in Indonesia. The primary focus of this work is on the characterization of bauxite with regards of scandium (Sc) occurrence and enrichment, as well as its opportunities for green technology applications. Understanding the enrichment of scandium in bauxite deposit will hopefully open new possibility to meet the needs for materials for green technology. This goal is in line with UN Sustainable Development Goals (SDGs) number 7 which focuses on a concerted global effort to ensure access to affordable, reliable, sustainable, and modern energy for all.

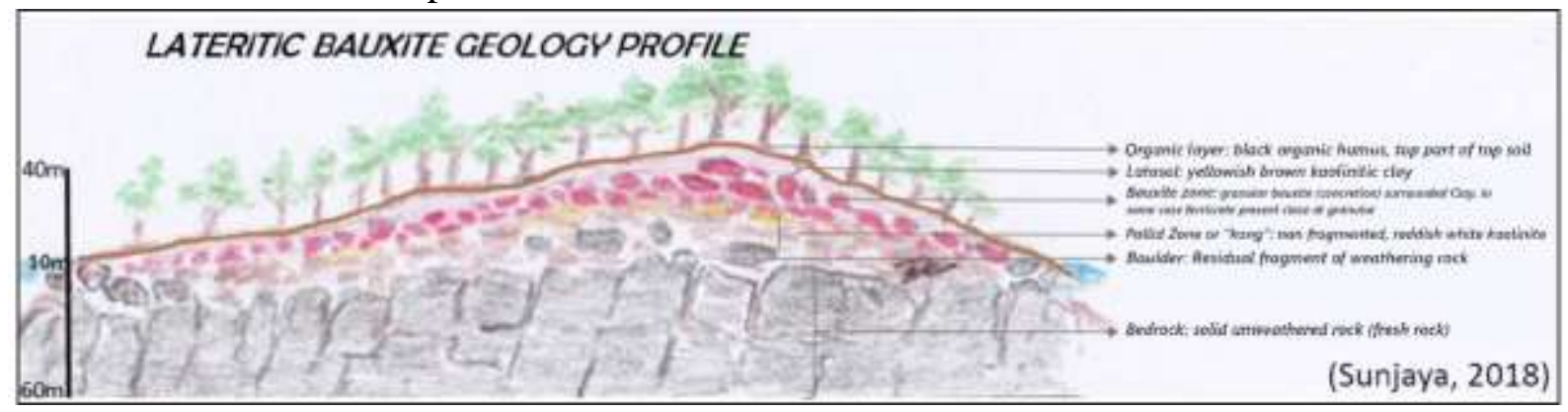

Figure 2. Geological profile of laterite bauxite deposits according to Sunjaya (2018, in Hindarto et al., 2019).

\section{METHODOLOGY}

This study combined both field data from PT. Aneka Tambang Tbk and lab work to characterize the scandium on bauxite deposit (Figure 3). A total of 33 weathered granitic rock samples from 9 test pits were collected by channel sampling.

The geological characteristics of bauxite are studied by petrography and XRD analyses on mineralogical assemblages. Major elemental concentration of the samples analyzed by using XRF. Thin section petrographic analysis conducted in Optical Geology Laboratory, Department of Geological Engineering, Faculty of Engineering, Gadjah Mada University. Meanwhile, XRD and XRF were performed at the Aneka Tambang's Laboratory. Rare earth elements, specifically scandium were determined by the ICP-MS method at Intertek 
Laboratory. Mineral chemistry analysis to determine elemental association conducted by SEM-BSE-EDS method using Hitachi FlexSEM 1000/EDS/AMICS in PT. Geoservices Laboratory.

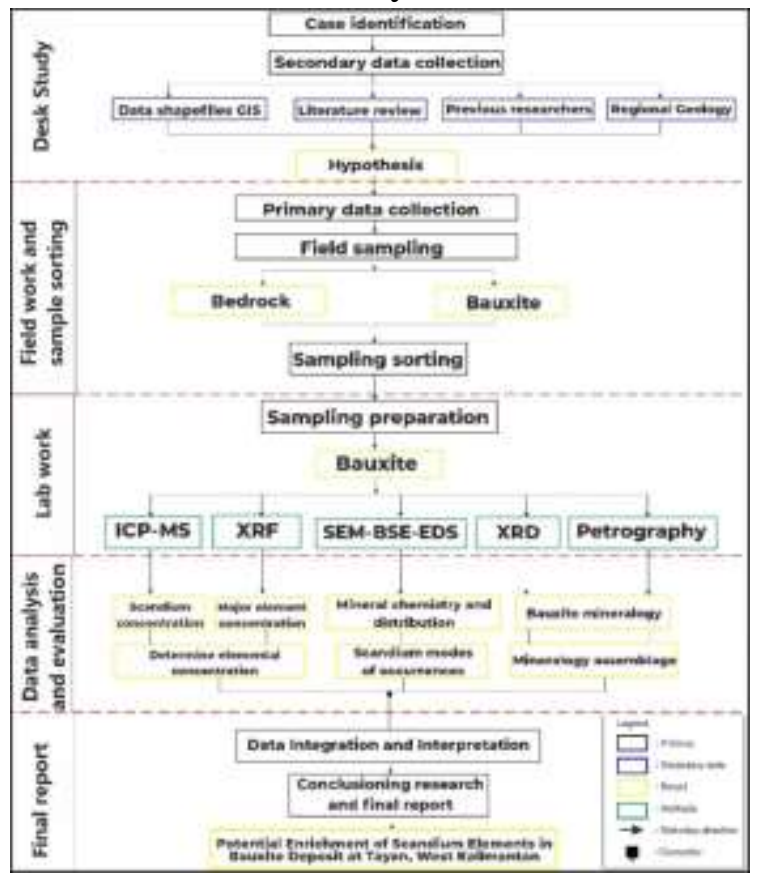

Figure 3. Research flowchart showing the general procedures and methods.

In the location called "Bukit 29", samples of laterite bauxite profiles were taken consisting of the latosol zone, bauxite zone, kong zone, and residual sediment zones from 9 testpit.

\section{RESULTS AND DISCUSSION Mineralogy}

Mineralogical data were obtained from the results of thin section petrographic analysis (Figure 4) and XRD. Based on microscopic observations, bauxite concretion sample shows concretion texture dominated by $\mathrm{Fe}$ and $\mathrm{Al}$ oxide-hydroxide. A detailed $\mathrm{XRD}$ analysis is required to description types of oxides and hydroxides that make up bauxite or other minerals that cannot be observed in thin sections.

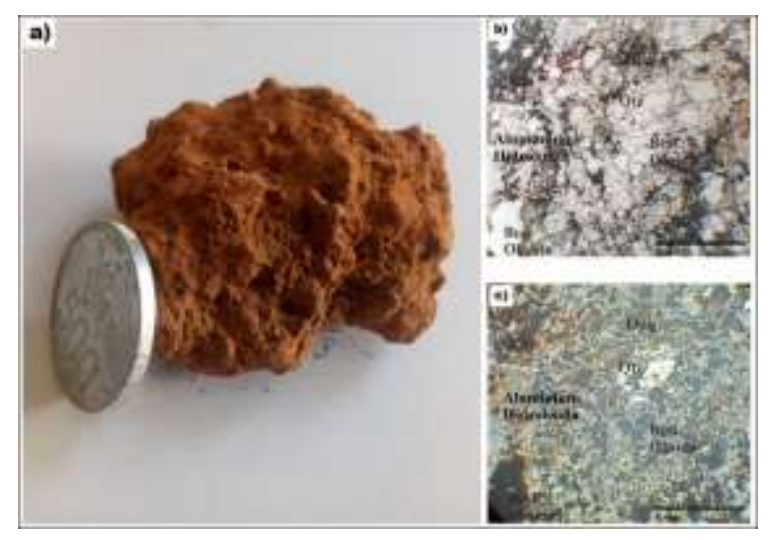

Figure 4. Microdiorite bauxite concretion sample. (a) megascopic scale of bauxite concretion, (b) parallel polarization petrographic of bauxite concretion, (c) cross polarization petrographic of bauxite concretion.

Detailed mineralogical studies based on XRD data revealed that the main constituents in bauxite (Table 1) are gibbsite (mean mineral percentage $71 \%$ ), quartz $(7.3 \%)$, hematite $(4.1 \%)$, goethite $(4.8 \%)$, kaolinite $(3.7 \%)$, illite $(9.3 \%)$, and nacrite $(7.6 \%)$. Meanwhile, dickite was only detected in bauxite in testpit 4 and tsumgallite was only detected in bauxite testpit number 7 .

Detailed mineralogical studies based on XRD data revealed that the main constituents in kong zone (Table 1) are quartz (mean mineral percentage $19 \%$ ), gibbsite $(15.3 \%)$, kaolinite $(1.8 \%)$ ), nacrite $(28.8 \%)$, dickite (27.1\%). Detailed mineralogical studies based on XRD data revealed that the main constituents in residu sediment zone (Table 1) are quartz (mean mineral percentage $45.3 \%$ ), gibbsite $(16.4 \%)$, nacrite $(16.2 \%)$, kaolinite (2.5\%), dickite $(12.7 \%)$.

Whole-rock geochemical data of the bauxite laterites from studied area was measured by XRF and ICPMS analysis. XRF analysis was performed on 9 samples of bauxite zones in each testpit, while ICP-MS analysis was performed on 33 samples including 9 samples of bauxite zones, 6 samples of kong zones, and 9 samples of residual sediment zones. 
Table 1. XRD data of bauxite, kong, and sediment residue zones on the study area.

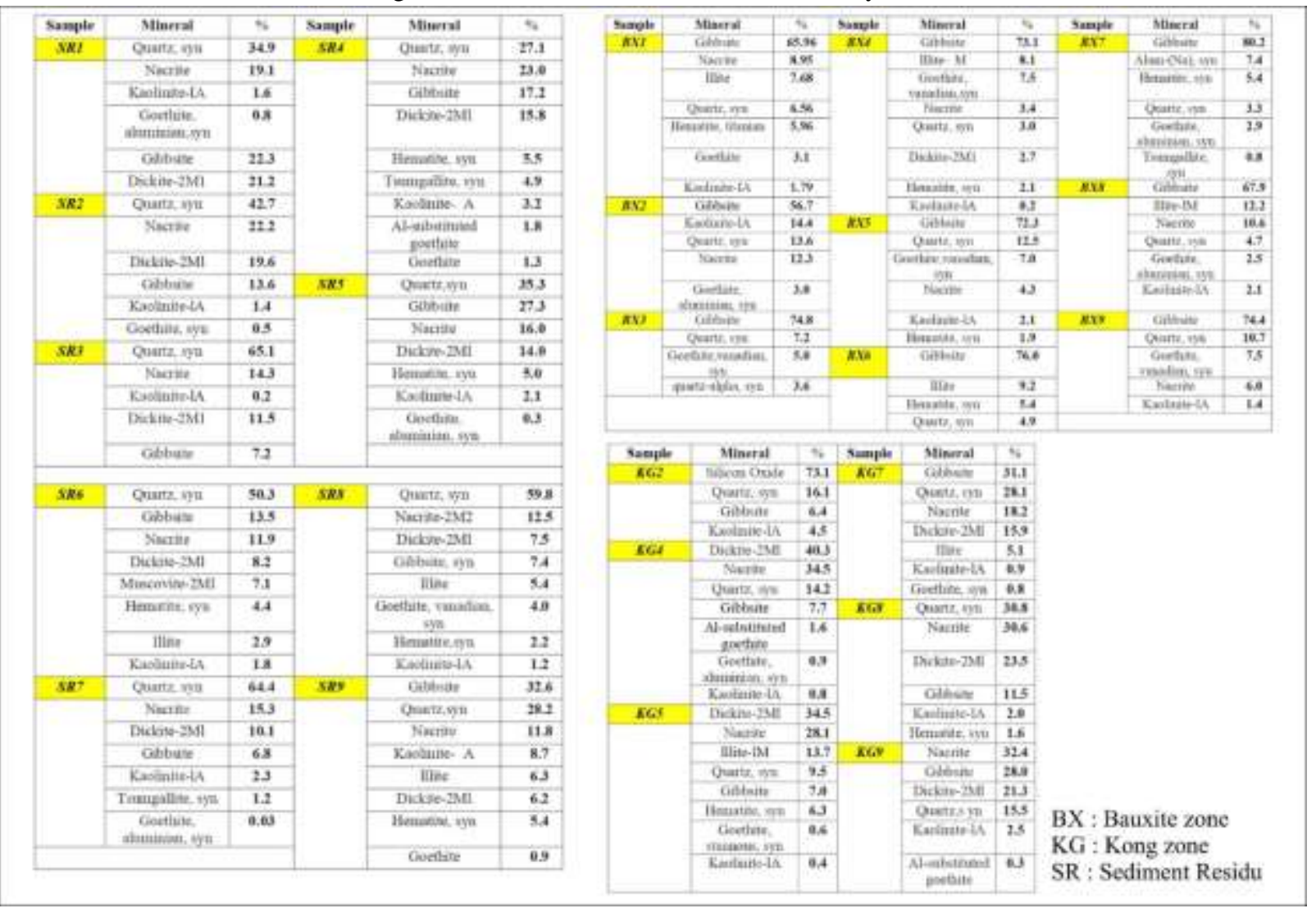

\section{Major Elements}

XRF was used to determine main oxide elemental concentration in bauxite samples.

Table 2). Based on the result, it was found that bauxite in study area was dominated by high $\mathrm{Al}_{2} \mathrm{O}_{3}$ and $\mathrm{Fe}_{2} \mathrm{O}_{3} . \mathrm{SiO}_{2}$ has a value range of $2.12-15.4 \%$ with an average value from entire samples is $8.5 \%$. $\mathrm{Al}_{2} \mathrm{O}_{3}$ has a value
The main oxides analyzed in this study were $\mathrm{SiO}_{2}, \mathrm{Al}_{2} \mathrm{O}_{3}, \mathrm{Fe}_{2} \mathrm{O}_{3}$, and $\mathrm{TiO}_{2}$ expressed in wt.\% (

range of $43.09-53.62 \%$ with an average value is $48.7 \%$. $\mathrm{Fe}_{2} \mathrm{O}_{3}$ has a value range of $6.26-24.83 \%$ with an average value is $14 \%$. $\mathrm{TiO}_{2}$ has a value range of $0.91-1.25 \%$ with an average value is $1 \%$.

Table 2. Major elements on the study area.

\begin{tabular}{|c|c|c|c|c|c|c|c|c|}
\hline \multirow{2}{*}{ Sample } & SiO2 & $\mathbf{A l 2 O 3}$ & $\mathbf{F e 2 O 3}$ & $\mathbf{T i O 2}$ & $\mathbf{R S i O 2}$ & $\begin{array}{c}\text { Total } \\
\text { major }\end{array}$ & LOI & Total \\
\cline { 2 - 9 } & $(\%)$ & $(\%)$ & $(\%)$ & $(\%)$ & $(\%)$ & $(\%)$ & $(\%)$ & $(\%)$ \\
\hline BX1 & 7,23 & 53,62 & 7,6 & 1,16 & 4,24 & 69,61 & 28,68 & 98,29 \\
\hline BX2 & 15,4 & 49,56 & 6,26 & 0,91 & 6,69 & 72,13 & 26,14 & 98,27 \\
\hline BX3 & 13,43 & 49,92 & 8,68 & 1,19 & 5,2 & 73,22 & 25,64 & 98,86 \\
\hline BX4 & 5,98 & 48,61 & 16,53 & 1,24 & 2,26 & 72,36 & 26,02 & 98,38 \\
\hline BX5 & 10,35 & 46,27 & 15,34 & 1,25 & 2,8 & 73,21 & 25,25 & 98,46 \\
\hline BX6 & 3,98 & 50,67 & 15,92 & 1,19 & 1,64 & 71,76 & 26,55 & 98,31 \\
\hline BX7 & 2,12 & 47,9 & 20,18 & 1,15 & 1,24 & 71,35 & 26,86 & 98,21 \\
\hline BX8 & 12,31 & 48,62 & 11,78 & 0,95 & 7,07 & 73,66 & 25,41 & 99,07 \\
\hline BX9 & 5,59 & 43,09 & 24,83 & 1,03 & 3,36 & 74,54 & 24,37 & 98,91 \\
\hline
\end{tabular}




\section{Rare Earth Elements}

ICP-MS was used to determine rare earth elements concentration in bauxite samples. REE analyzed in this method includes: $\mathrm{La} \mathrm{Ce}$,
Pr, Nd, Sm, Eu, Gd, Tb, Dy, Ho, Er, Tm, Yb, $\mathrm{Lu}, \mathrm{Y}$, and $\mathrm{Sc}$ which expressed in ppm (Table 3 ). The result of scandium concentration as a focused on this research is shows by orange line, which equals to $50.9 \mathrm{ppm}$.

Table 3. Rare earth elements data on the study area

\begin{tabular}{|c|c|c|c|c|c|c|c|c|c|c|c|}
\hline \multirow[t]{2}{*}{ Sample } & \multirow{2}{*}{$\begin{array}{c}\text { Parent rock } \\
\text { (previous study by } \\
\text { PT. Antam Unit } \\
\text { Geomin) }\end{array}$} & $\mathbf{L a}$ & $\mathrm{Ce}$ & Pr & Nd & Sm & Eu & Gd & $\mathrm{Tb}$ & Dy & Ho \\
\hline & & \multicolumn{6}{|c|}{ LREE } & & & & \\
\hline LA1 & \multirow{3}{*}{ Granodiorit } & 4.27 & 9.62 & 1.11 & 4.73 & 1.07 & 0.36 & 1.11 & 0.14 & 0.87 & 0.15 \\
\hline BX1 & & 1.5 & 3.66 & 0.41 & 1.82 & 0.44 & 0.17 & 0.4 & 0.07 & 0.43 & 0.07 \\
\hline SR1 & & 4.66 & 10.7 & 1.26 & 5.4 & 1.26 & 0.43 & 1.28 & 0.17 & 1.02 & 0.18 \\
\hline LA2 & \multirow{4}{*}{ Granodiorit } & 5.06 & 11.1 & 1.28 & 5.37 & 1.19 & 0.36 & 1.2 & 0.16 & 0.93 & 0.16 \\
\hline BX2 & & 4.93 & 11.8 & 1.36 & 5.74 & 1.42 & 0.47 & 1.54 & 0.22 & 1.29 & 0.23 \\
\hline KG2 & & 7.64 & 19 & 2.12 & 9.01 & 2.02 & 0.57 & 2 & 0.27 & 1.62 & 0.28 \\
\hline SR2 & & 4.66 & 10.2 & 1.14 & 4.88 & 1.12 & 0.34 & 1.11 & 0.16 & 0.93 & 0.16 \\
\hline LA3 & \multirow{3}{*}{ Granodiorit } & 4.66 & 10.7 & 1.22 & 5.2 & 1.15 & 0.39 & 1.14 & 0.16 & 0.99 & 0.17 \\
\hline BX3 & & 2.15 & 5.36 & 0.67 & 2.85 & 0.67 & 0.29 & 0.71 & 0.09 & 0.6 & 0.11 \\
\hline SR3 & & 5.6 & 12.8 & 1.43 & 5.93 & 1.4 & 0.44 & 1.4 & 0.19 & 1.13 & 0.19 \\
\hline LA4 & \multirow{4}{*}{ Mikrodiorit } & 1.48 & 3.64 & 0.4 & 1.83 & 0.46 & 0.17 & 0.42 & 0.06 & 0.39 & 0.07 \\
\hline BX4 & & 0.18 & 2.45 & 0.08 & 0.4 & 0.16 & 0.07 & 0.12 & 0.02 & 0.13 & 0.02 \\
\hline KG4 & & 3.36 & 9.26 & 0.95 & 4.21 & 1.08 & 0.39 & 1.07 & 0.15 & 0.95 & 0.18 \\
\hline SR4 & & 1.62 & 4.08 & 0.44 & 2 & 0.52 & 0.19 & 0.48 & 0.07 & 0.44 & 0.08 \\
\hline LA5 & \multirow{4}{*}{ Mikrodiorit } & 1.6 & 3.82 & 0.43 & 1.82 & 0.45 & 0.15 & 0.41 & 0.06 & 0.36 & 0.06 \\
\hline BX5 & & 0.43 & 2.06 & 0.18 & 0.84 & 0.31 & 0.2 & 0.27 & 0.05 & 0.31 & 0.05 \\
\hline KG5 & & 8.38 & 14.1 & 1.79 & 6.51 & 1.18 & 0.39 & 1 & 0.13 & 0.73 & 0.14 \\
\hline SR5 & & 2.26 & 5.19 & 0.64 & 2.89 & 0.74 & 0.31 & 0.75 & 0.12 & 0.87 & 0.16 \\
\hline LA6 & \multirow[t]{4}{*}{ Mikrodiorit } & 1.36 & 3.4 & 0.36 & 1.56 & 0.39 & 0.13 & 0.36 & 0.05 & 0.35 & 0.06 \\
\hline BX6 & & 0.31 & 1.08 & 0.08 & 0.35 & 0.08 & 0.04 & 0.08 & 0.01 & 0.07 & 0.01 \\
\hline KG6 & & 2.85 & 7.11 & 0.68 & 2.59 & 0.63 & 0.21 & 0.58 & 0.1 & 0.63 & 0.12 \\
\hline SR6 & & 2.23 & 6.55 & 0.57 & 2.41 & 0.61 & 0.19 & 0.57 & 0.09 & 0.58 & 0.11 \\
\hline LA7 & \multirow[t]{4}{*}{ Diorit } & 2.85 & 6.26 & 0.71 & 3.13 & 0.69 & 0.25 & 0.65 & 0.09 & 0.52 & 0.1 \\
\hline BX7 & & 0.43 & 1.7 & 0.13 & 0.57 & 0.16 & 0.07 & 0.16 & 0.02 & 0.14 & 0.02 \\
\hline KG7 & & 4.83 & 12.5 & 1.27 & 5.6 & 1.28 & 0.52 & 1.2 & 0.16 & 0.99 & 0.17 \\
\hline SR7 & & 2.56 & 5.95 & 0.66 & 2.89 & 0.7 & 0.25 & 0.63 & 0.09 & 0.54 & 0.1 \\
\hline BX8 & \multirow{3}{*}{ Diorit } & 1.93 & 3.84 & 0.38 & 1.48 & 0.3 & 0.08 & 0.28 & 0.04 & 0.23 & 0.04 \\
\hline KG8 & & 3.18 & 6.3 & 0.72 & 3.08 & 0.76 & 0.27 & 1.12 & 0.11 & 0.79 & 0.16 \\
\hline SR8 & & 1.84 & 4.21 & $\begin{array}{l}0.46 \\
\end{array}$ & 1.98 & 0.51 & 0.16 & 0.45 & 0.07 & 0.48 & 0.09 \\
\hline LA9 & \multirow{4}{*}{ Mikrodiorit } & 0.68 & 2.49 & 0.2 & 0.96 & 0.29 & 0.11 & 0.24 & 0.04 & 0.28 & 0.05 \\
\hline $\mathrm{BX} 9$ & & 0.38 & 1.6 & 0.11 & 0.49 & 0.13 & 0.06 & 0.11 & 0.02 & 0.13 & 0.02 \\
\hline KG9 & & 1.04 & 4.69 & 0.41 & 2 & 0.68 & 0.27 & 0.74 & 0.13 & 0.89 & 0.18 \\
\hline SR9 & & 1.07 & 4.79 & 0.38 & 1.77 & 0.6 & 0.23 & 0.58 & 0.1 & 0.71 & 0.14 \\
\hline
\end{tabular}




\begin{tabular}{|c|c|c|c|c|c|c|c|c|c|c|c|}
\hline \multirow[t]{2}{*}{ Sample } & \multirow[t]{2}{*}{$\begin{array}{c}\text { Parent rock } \\
\text { (previous study by } \\
\text { PT. Antam Unit } \\
\text { Geomin) }\end{array}$} & Ho & $\mathbf{E r}$ & Tm & $\mathbf{Y b}$ & Lu & $\mathbf{Y}$ & \multirow[t]{2}{*}{$\mathrm{Sc}$} & \multirow[t]{2}{*}{ LREE } & \multirow[t]{2}{*}{ HREE } & \multirow[t]{2}{*}{ REY } \\
\hline & & \multicolumn{6}{|c|}{ HREE } & & & & \\
\hline LA1 & \multirow{3}{*}{ Granodiorit } & 0.15 & 0.36 & 0.04 & 0.28 & 0.04 & 3.26 & 15.5 & 21.16 & 6.25 & 42.91 \\
\hline BX1 & & 0.07 & 0.2 & 0.03 & 0.2 & 0.03 & 1.32 & 19.6 & 8 & 2.75 & 30.35 \\
\hline SR1 & & 0.18 & 0.43 & 0.05 & 0.33 & 0.04 & 3.93 & 22.2 & 23.71 & 7.43 & 53.34 \\
\hline LA2 & \multirow{4}{*}{ Granodiorit } & 0.16 & 0.37 & 0.04 & 0.26 & 0.04 & 3.51 & 15.2 & 24.36 & 6.67 & 46.23 \\
\hline BX2 & & 0.23 & 0.56 & 0.06 & 0.4 & 0.05 & 4.79 & 15.7 & 25.72 & 9.14 & 50.56 \\
\hline KG2 & & 0.28 & 0.7 & 0.08 & 0.54 & 0.08 & 6.35 & 17.1 & 40.36 & 11.92 & 69.38 \\
\hline SR2 & & 0.16 & 0.38 & 0.04 & 0.26 & 0.03 & 3.4 & 15 & 22.34 & 6.47 & 43.81 \\
\hline LA3 & \multirow{3}{*}{ Granodiorit } & 0.17 & 0.42 & 0.05 & 0.3 & 0.04 & 3.69 & 15.9 & 23.32 & 6.96 & 46.18 \\
\hline $\mathrm{BX} 3$ & & 0.11 & 0.27 & 0.03 & 0.24 & 0.03 & 2.2 & 18.1 & 11.99 & 4.28 & 34.37 \\
\hline SR3 & & 0.19 & 0.49 & 0.05 & 0.35 & 0.05 & 4.26 & 15.9 & 27.6 & 8.11 & 51.61 \\
\hline LA4 & \multirow{4}{*}{ Mikrodiorit } & 0.07 & 0.2 & 0.03 & 0.18 & 0.03 & 1.25 & 44.3 & 7.98 & 2.63 & 54.91 \\
\hline BX4 & & 0.02 & 0.06 & 0.02 & 0.07 & 0.01 & 0.33 & 44 & 3.34 & 0.78 & 48.12 \\
\hline KG4 & & 0.18 & 0.49 & 0.07 & 0.52 & 0.08 & 3.55 & 44.6 & 19.25 & 7.06 & 70.91 \\
\hline SR4 & & 0.08 & 0.23 & 0.03 & 0.21 & 0.03 & 1.52 & 48.2 & 8.85 & 3.09 & 60.14 \\
\hline LA5 & \multirow{4}{*}{ Mikrodiorit } & 0.06 & 0.16 & 0.02 & 0.18 & 0.02 & 1.15 & 35 & 8.27 & 2.42 & 45.69 \\
\hline BX5 & & 0.05 & 0.14 & 0.02 & 0.15 & 0.02 & 0.83 & 50.9 & 4.02 & 1.84 & 56.76 \\
\hline KG5 & & 0.14 & 0.35 & 0.05 & 0.37 & 0.05 & 2.65 & 30.2 & 32.35 & 5.47 & 68.02 \\
\hline SR5 & & 0.16 & 0.48 & 0.07 & 0.54 & 0.07 & 3.05 & 55.4 & 12.03 & 6.11 & 73.54 \\
\hline LA6 & \multirow[t]{4}{*}{ Mikrodiorit } & 0.06 & 0.16 & 0.02 & 0.18 & 0.03 & 1.05 & 43.2 & 7.2 & 2.26 & 52.66 \\
\hline BX6 & & 0.01 & 0.04 & 0.0099 & 0.04 & 0.01 & 0.25 & 28.3 & 1.94 & 0.5199 & 30.7599 \\
\hline KG6 & & 0.12 & 0.34 & 0.05 & 0.36 & 0.06 & 1.97 & 46.6 & 14.07 & 4.21 & 64.88 \\
\hline SR6 & & 0.11 & 0.3 & 0.04 & 0.33 & 0.05 & 1.95 & 39.9 & 12.56 & 4.02 & 56.48 \\
\hline LA7 & \multirow[t]{4}{*}{ Diorit } & 0.1 & 0.27 & 0.03 & 0.26 & 0.04 & 1.94 & 27.3 & 13.89 & 3.9 & 45.09 \\
\hline BX7 & & 0.02 & 0.07 & 0.01 & 0.08 & 0.01 & 0.43 & 42 & 3.06 & 0.94 & 46 \\
\hline KG7 & & 0.17 & 0.45 & 0.06 & 0.46 & 0.07 & 3.32 & 44.3 & 26 & 6.88 & 77.18 \\
\hline SR7 & & 0.1 & 0.26 & 0.04 & 0.27 & 0.04 & 1.85 & 30.5 & 13.01 & 3.82 & 47.33 \\
\hline B X8 & \multirow{3}{*}{ Diorit } & 0.04 & 0.12 & 0.01 & 0.11 & 0.02 & 0.98 & 13.7 & 8.01 & 1.83 & 23.54 \\
\hline KG8 & & 0.16 & 0.46 & 0.07 & 0.55 & 0.08 & 2.7 & 36.1 & 14.31 & 6.04 & 56.45 \\
\hline SR8 & & 0.09 & 0.27 & 0.04 & 0.31 & 0.05 & 1.67 & 26.6 & 9.16 & 3.43 & 39.19 \\
\hline LA9 & \multirow{4}{*}{ Mikrodiorit } & 0.05 & 0.14 & 0.02 & 0.15 & 0.03 & 0.82 & 52.9 & 4.73 & 1.77 & 59.4 \\
\hline BX9 & & 0.02 & 0.05 & 0.01 & 0.07 & 0.01 & 0.33 & 45.3 & 2.77 & 0.75 & 48.82 \\
\hline KG9 & & 0.18 & 0.53 & 0.08 & 0.53 & 0.08 & 3.44 & 38.3 & 9.09 & 6.6 & 53.99 \\
\hline SR9 & & 0.14 & 0.42 & 0.06 & 0.47 & 0.07 & 2.75 & 41.2 & 8.84 & 5.3 & 55.34 \\
\hline
\end{tabular}

\section{Modes of Occurrences of Scandium}

Mode of occurrences of scandium were obtained through SEM-BSE-EDS analysis using back scattered electron and energy dispersive spectrometer methods. Backscattered electron image data from bauxite sample in the study area shows that Sc is hosted in both iron oxide and aluminum oxide.Kesalahan! Sumber referensi tidak ditemukan. shows the presence of scandium in iron hydroxide, namely goethite $\left(\mathrm{Fe}_{2} \mathrm{O}_{3} \cdot \mathrm{H}_{2} \mathrm{O}\right)$, while aluminum hydroxide is concentrated in the mineral gibbsite $\left(\mathrm{Al}(\mathrm{OH})_{3}\right)$. In addition, ilmenite is found in the sample which is associated with goethite and gibbsite. Ilmenite, which is iron oxide of titanium, was present as a result of the positive correlation of the elements $\mathrm{Sc}$ and $\mathrm{Ti}$ shown in Figure 10.

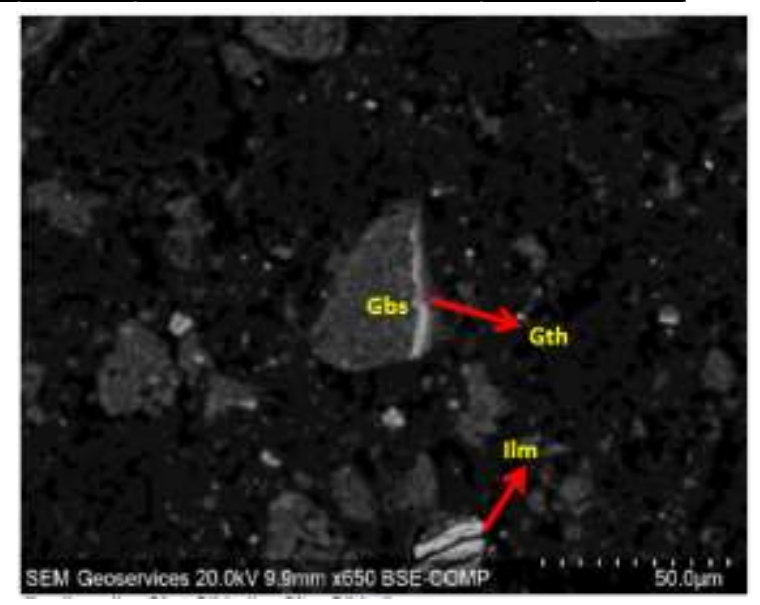

Figure 5. Backscattered electron image of selection analyzed spots in bauxite sample.

According to Vind et al., (2018), an indication of $\mathrm{Ti}$ is occurs in hematite mineral lattice or due to the occurrence of nanoscale titanium dioxide phases in the matrix. However, the presence of titanium dioxide is extremely rare of total scandium in the bauxite residue.

Systematic SEM-EDS mapping confirms the presence of scandium is mainly hosted in goethite, where $\mathrm{Sc}^{3+}$ substitutes $\mathrm{Fe}^{3+}$ in goethite crystal lattice (Figure 6). Scandium 
is also known to be hosted in gibbsite as a substitute of $\mathrm{Al}^{3+}$ in gibbsite crystal lattice (Figure 7).

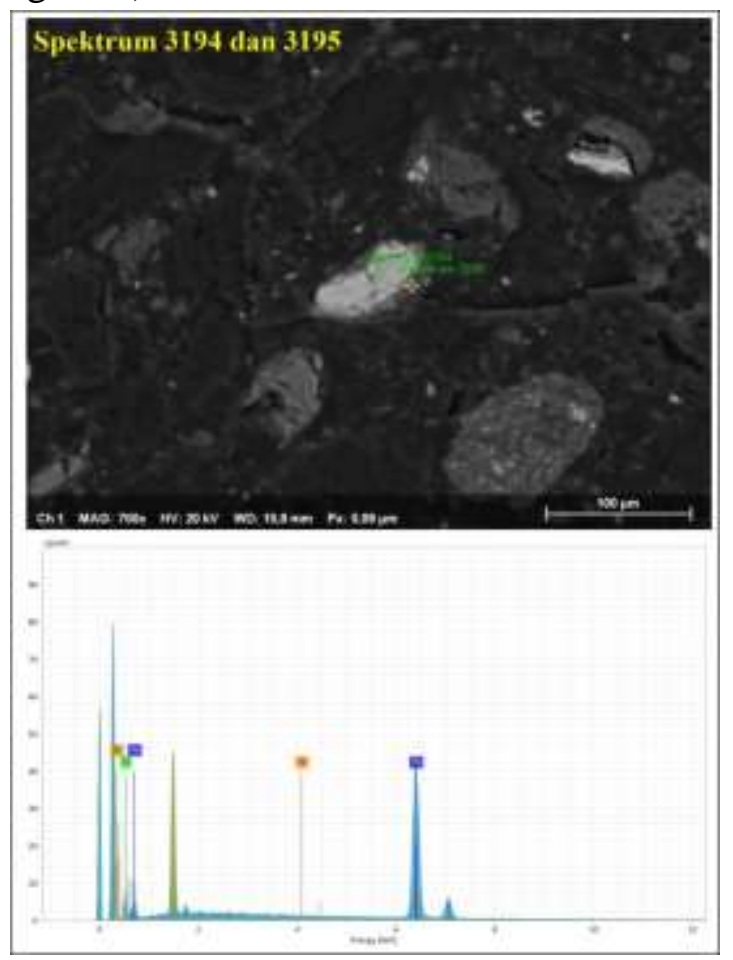

Figure 6. Backscattered electron image shows Sc on goethite contained in bauxite sample.

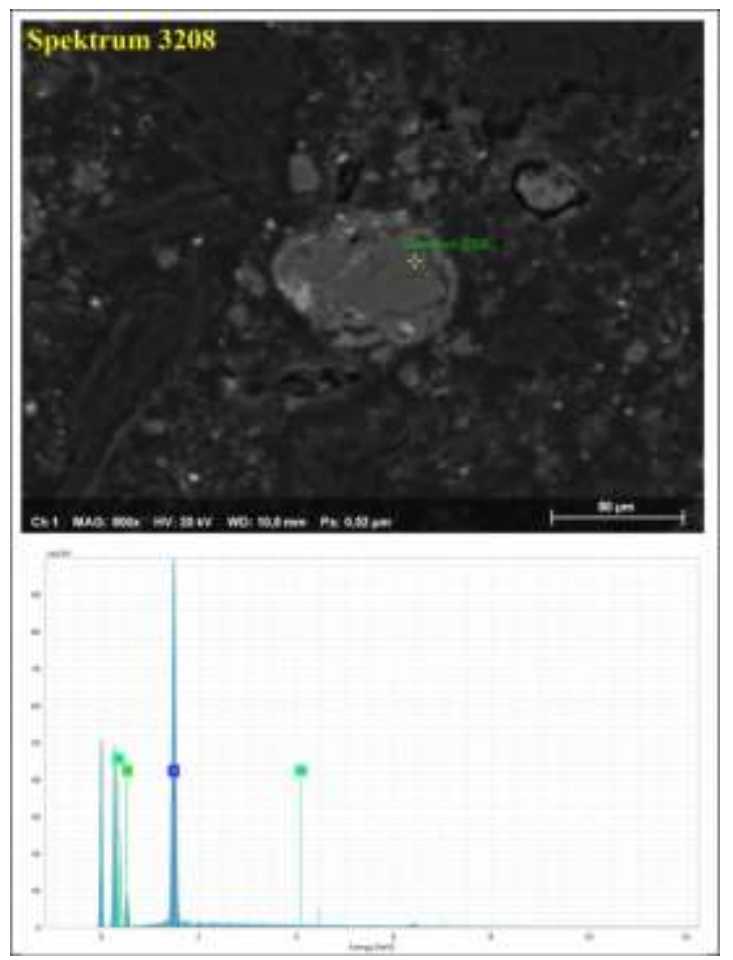

Figure 7. Backscattered electron image shows Sc on gibbsite contained in bauxite sample.

Discussion
The characterizations that include texture and mineralogical parameters of bauxite of the study area are used for interpretation of the lateritization process. According to Delvigne (1998, in Wulansari et al., 2016), concretion texture in thin section has cement components in the form of iron hydroxide minerals and aluminum hydroxide minerals. It shown on the bauxite sample in study area, which iron hydroxide representative by goethite and aluminum hydroxide representative by gibbsite.

The concretion texture of the bauxite microdiorite shows dominant mineral distribution of cement is by iron hydroxide representative by goethite. Iron hydroxide and the presence of quartz minerals indicate that the dissolving stage of mobile minerals in the bauxite formation process has not been effective. Meanwhile, a small amount of aluminum hydroxide indicates that water circulation in the bauxite formation process does not work predominantly.

The presence of the mineral goethite scattered to form an aphanitic texture and gives it a distinctive yellowish-brown color. This draws typical concretion texture of bauxite composed of iron oxide minerals.

In the ferruginous laterite horizon (Figure 8 ), the iron hydroxide mineral present with goethite is hematite. Based on the results, an average percentage proportion of hematite was relatively smaller (4.1\%) compared to goethite $(4.8 \%)$. In a thin section observation, hematite in bauxite is characterized by reddish brown color. The presence of hematite describes the formation process of bauxite under oxidizing conditions.

Kaolinite is the main silicate mineral in the laterite profile which performed in saprolite horizon (Figure 5.3). Kaolinite content in the laterite profile will increase 
downward to the saprolite zone or what is known as bauxite zone. In addition, kaolinite was also found to be concentrated among the bauxite concretion cement. Under certain conditions, kaolinite will transform into gibbsite minerals, which explains the occurrences of kaolinite in bauxite.

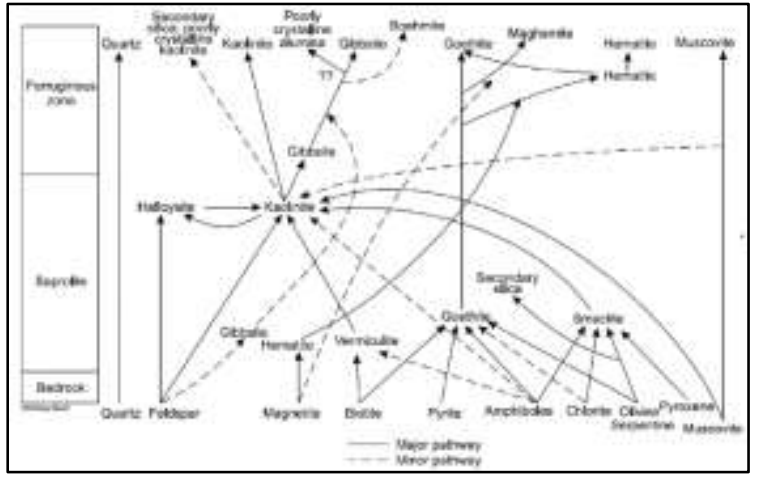

Figure 8. Secondary mineral formation pathways in laterite bauxite deposit (Anand and Paine, 2002).

Based on XRF analysis, correlation between main oxides was compared to see the lateritization process through binary diagrams. The results of the binary diagram show a positive correlation between $\mathrm{Al}_{2} \mathrm{O}_{3}$ vs $\mathrm{SiO}_{2}(\mathrm{R} 2=0.0163), \mathrm{Al}_{2} \mathrm{O}_{3}$ vs $\mathrm{TiO}_{2}(\mathrm{R} 2=$ 0.0195), $\mathrm{Al}_{2} \mathrm{O}_{3}$ vs $\mathrm{RSiO}_{2}(\mathrm{R} 2=0.0324)$. While the binary diagram shows a negative correlation between $\mathrm{Al}_{2} \mathrm{O}_{3}$ vs $\mathrm{Fe}_{2} \mathrm{O}_{3}(\mathrm{R} 2=$ 0.586).

Based on ICP-MS analysis, the concentration of REE in bauxite zone in the study area varied between $23.54 \mathrm{ppm}$ to 77.18 ppm (Table 3). In comparison scandium concentration with major oxide from 9 testpit, various correlation patterns were obtained (Figure 10). The correlation was carried out to see the potential occurrences of minerals carrying scandium through major oxide. The results of correlation showed that the presence of the scandium element had a positive correlation with the elements of $\mathrm{Fe}$ $(\mathrm{R} 2=0.637)$ and $\mathrm{Ti}(\mathrm{R} 2=0.282)$.

The evidence of potential for scandium element enrichment in study area was carried out by comparing the REE concentration with Greek's Karst Bauxite REE values Figure 11). The results show that the average REE content of bauxite in study area was quite low, but Sc values just slightly higher compared to the other elements.

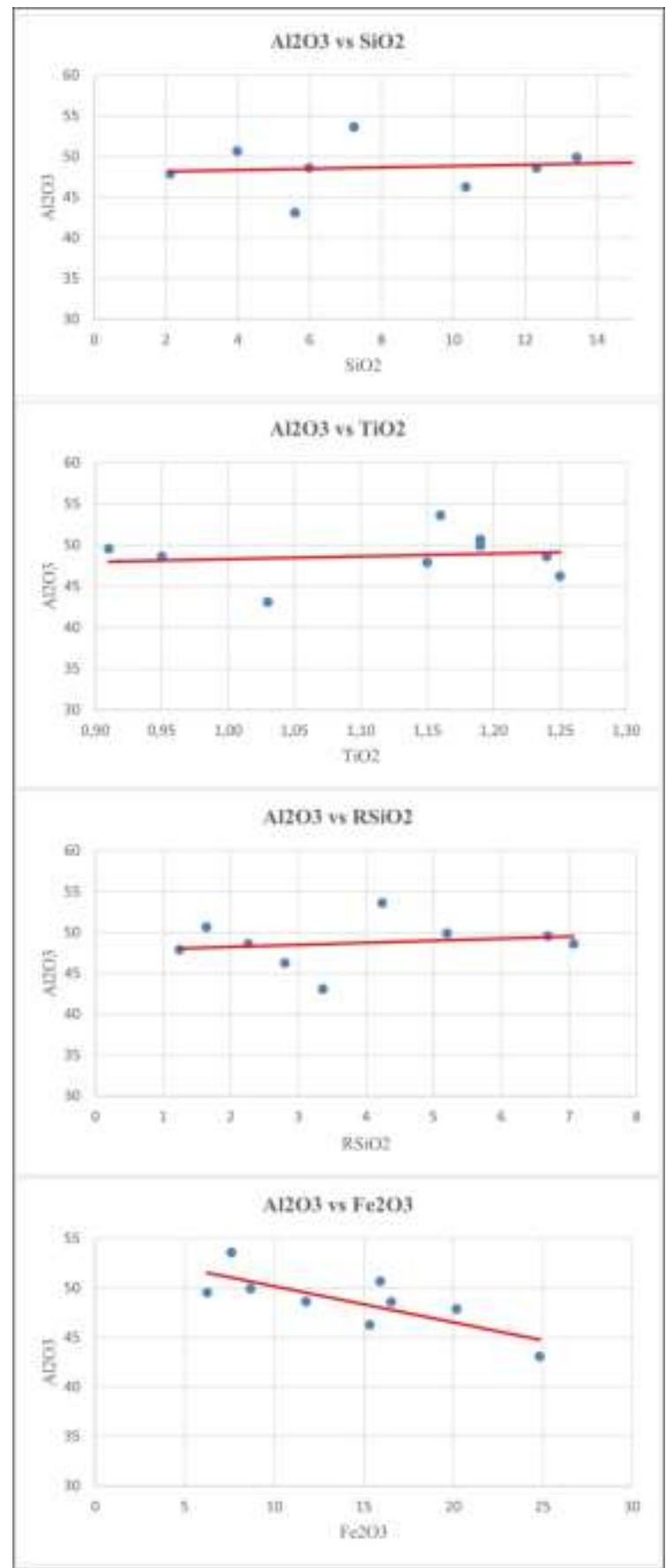

Figure 9. Binary diagram of elemental oxide correlations between $\mathrm{Al}_{2} \mathrm{O}_{3}$ vs $\mathrm{SiO}_{2}, \mathrm{Al}_{2} \mathrm{O}_{3}$ vs $\mathrm{TiO}_{2}$, $\mathrm{Al}_{2} \mathrm{O}_{3}$ vs $\mathrm{RsiO}_{2}$, and $\mathrm{Al}_{2} \mathrm{O}_{3}$ vs $\mathrm{Fe}_{2} \mathrm{O}_{3}$. 


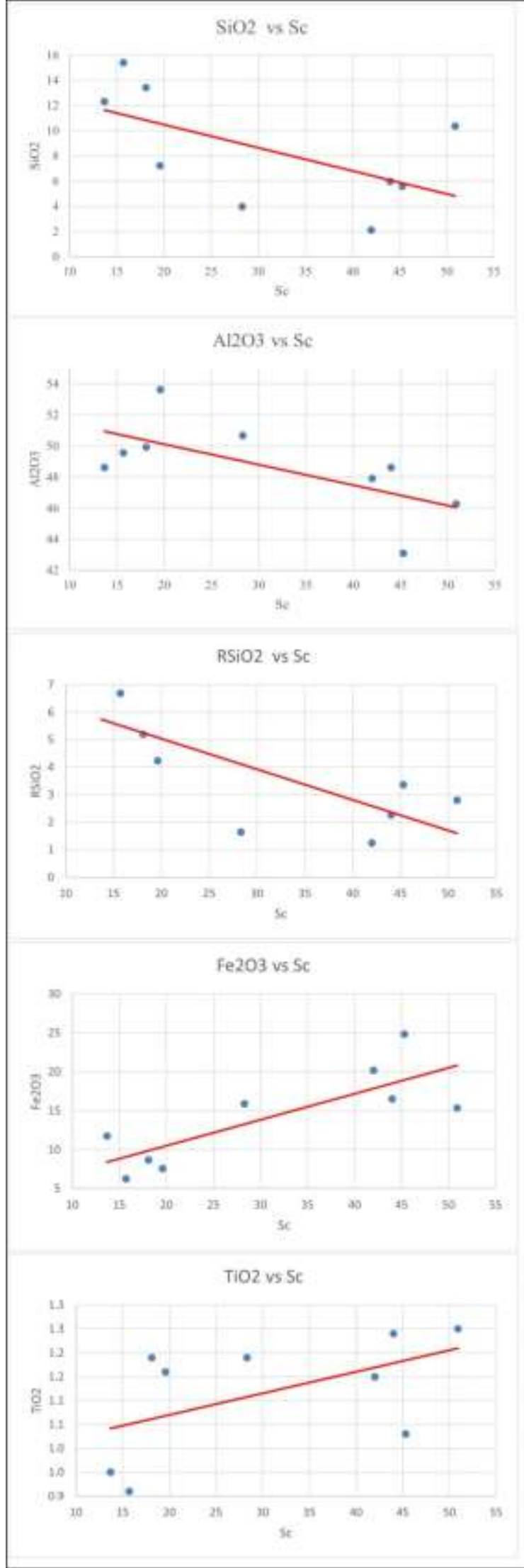

Figure 10. Correlation between major oxide and scandium content in the bauxite sample.

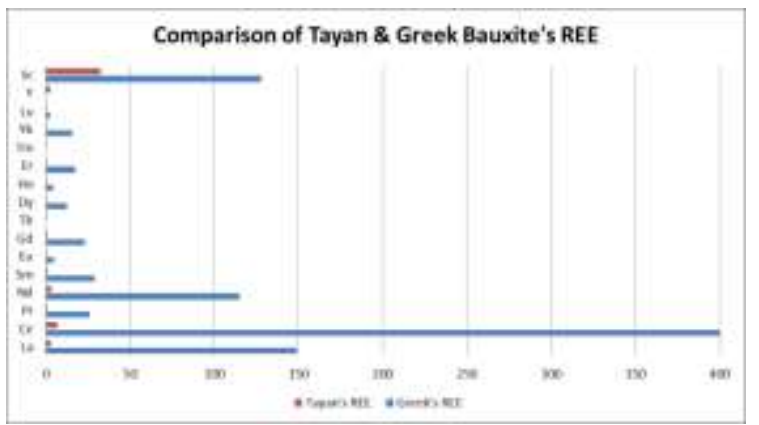

Figure 11. Comparison of REE values in bauxite deposit in study area with Greek's Karst Bauxite.

Systematic SEM-BSE-EDS analysis proves that scandium accumulates in $\mathrm{Fe}$ and Al hydroxide in the bauxite zone. In this study, iron hydroxide minerals which hosted scandium is goethite, while aluminum hydroxide minerals which hosted scandium is gibbsite.

Geochemical data in the correlation diagram shows that $\mathrm{Sc}$ is most likely present in iron hydroxide. Scandium will not tend to be easily adsorbed by other minerals, but it will be easier to substitute for other minerals which have relatively the same trivalent coefficient value. Scandium enrichment will be mainly concentrated in weathering products rich in iron hydroxide, especially in the bauxite zone. Geochemically, the substitution of $\mathrm{Fe}^{3+}$ and $\mathrm{Al}^{3+}$ by $\mathrm{Sc}^{3+}$ can result from a combination of three states: [1] the same partition coefficient, [2] a relatively same atomic radii, and [3] the same six-fold coordination number. The existence of scandium at any concentration levels in weathered granitic rocks encompasses a critical value, especially on economic perspective (Maulana et al., 2016). Therefore, application of $\mathrm{Sc}$ is needed in the near future.

\section{Fuel Cells as a Sustainable Source of Energy}

In general terms, fuel cell is an electrochemical devices that changes over 
chemical energy and oxygen source into an electrical current, additionally water, $\mathrm{CO}_{2}$, and heat (Duyvesteyn and Putnam, 2014). Its components consist like batteries, such as electrolytes, anodes, and cathodes. Fuel cell operation is exothermic, so it needs quite hot temperature and unstoppable material to proceed continuously. Many types of fuel cell has been developed, but Solid Oxide Fuell Cell (SOFCs) is the most common usage because it has a wide scale usage such as residential scale power plant, small and large industry, and electric vehicle with huge power generated of $1 \mathrm{~kW}-100 \mathrm{MW}$ (Singhal and Kendall, 2003).

SOFCs is using hard ceramic material as the solid electrolyte between anode and cathode to separate reactants with temperatures of approximately $1,000{ }^{0} \mathrm{C}$, pressure under 1 atm, resulting energy efficiency ranging from $65-80 \%$. Solid oxide fuel cells convert the energy in natural gas to electricity which avoids sulfur content because it can poisoned the reaction. Fuel for SOFCs could be used from hydrogen gas. In addition, methane gas $\left(\mathrm{CH}_{4}\right)$ can also be used on condition through a reforming process to change the molecular shape of $\mathrm{CH} 4$ to $\mathrm{H} 2$ and $\mathrm{CO}_{2}$.

In fact, scandium is ideal electrolyte to be used as a stabilizing agent (SZ). It is because scandium (ScSZ) considerably good ionic electrical conductor compare to yttrium (YSZ). Detail principle reaction of SOFC is as follow (Figure 12):

1. Electrolyte flows oxygen ions from cathode to anode or vice versa to make reduction reaction.

2. On the anode side, fuel and electrolyte meet. $\mathrm{H} 2$ gas as fuel enters and reacts with oxygen to make an oxidation reaction to produce water vapor, electrons, and heat energy.
3. Electrons move through the external circuit to enter cathode side. On the cathode side, this is where electrons meet with oxygen to carry out the reduction reaction.

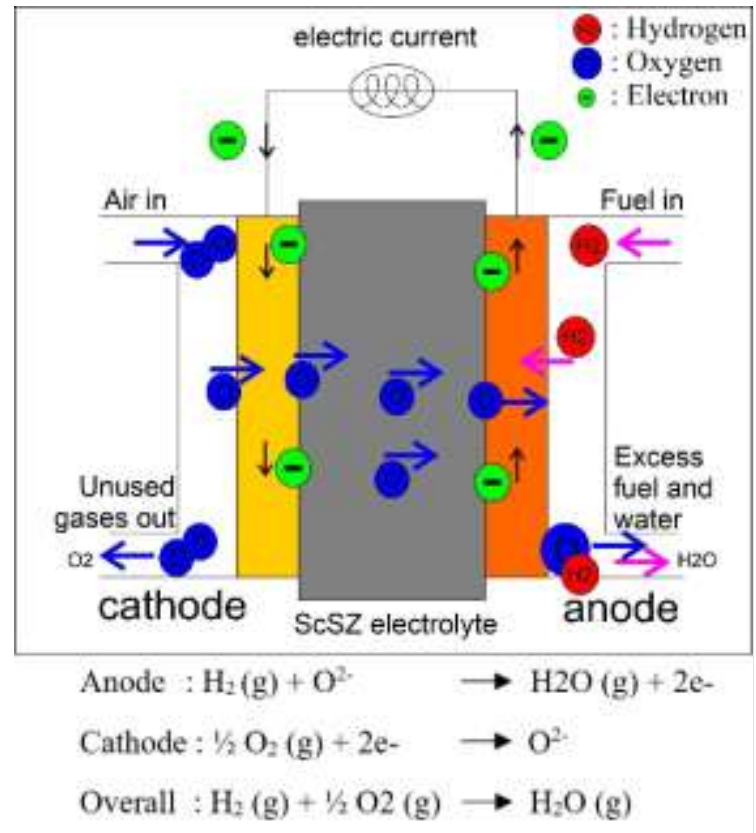

Figure 12. Solid oxide fuel cell chemistry systems (modified from Duyvesteyn and Putnam, 2014).

\section{CONCLUSION}

Critical Raw Materials including scandium are emerging issues for supporting green technology needs and a line with Sustainable Development Goals (SDGs). Bauxite in study area shows a concretion texture which is predominantly composed of iron hydroxide and aluminum hydroxide minerals. Scandium concentration on study area reaches up to 50,9 ppm in test pit number 5 on bauxite horizon. This scandium enrichment beyond the minimum limit of the scandium resource parameter according to Shaoquan and Suqing (1996), so it can be considerable as resources and worthy exploitation. Lateritic conditions that developed during weathering allowed Sc to substitute $\mathrm{Fe}$ and $\mathrm{Al}$ hydroxides minerals. In this study, iron hydroxide minerals which host scandium is goethite, while aluminum 
hydroxide minerals which host scandium is gibbsite. Based on the scandium enrichment mechanism shown in this study, laterite bauxite has the potential to be a viable scandium resource in reaching new milestone energy power today. Scandium could be a clean leader for emerging green technology. Understanding the enrichment in which scandium occurs in bauxite deposit will hopefully open the new possibility to meet the needs for SOFCs.

\section{ACKNOWLEDGEMENTS}

We gratefully acknowledge PT. Aneka Tambang Tbk Unit Geomin and Unit Bisnis Pertambangan Bauksit Tayan for the support of this study.

\section{REFERENCES}

Anand, R. R., Paine, M., (2002) "Regolith geology of the Yilgarn Craton, Western Australia: Implications for exploration", Australian Journal of Earth Sciences, 49, pp. 3-162.

Duyvesteyn, W. P. C. and Putnam, G., (2014) "Scanᄀdium: A review of the element, its character-istic, and current and emerging commercial application", EMC Metal Corporation White Paper, pp. 12.

European Commission, (2017) "Study on the review of the list of Critical Raw Materials Criticality Assessments, Luxembourg", Publications Office of the European Union, pp. 93.

Hindarto, A., Sunjaya, D., Semedie T., Sutopo, B., and Subandrio, A. S., (2019) "Utilization of geological research data and exploration grade distribution in preparation of detailed geological maps and ore characteristics distribution at the Tayan bauxite mine", MGEI Proceedings: Unlocking Concealed and Complex Deposits, pp.100-103.

Horovitz, C. T., (1975) Scandium: Its Occurrence, Chemistry, Physics, Metallurgy, Biology, And Technology, [extensive bibliography for each chapter], Academic Press, pp. 489.

Maulana, A., Sanematsu, K., and Sakakibara, M., (2016) "An Overview on the Possibility of
Scandium and REE Occurrence in Sulawesi, Indonesia", Indonesian Journal on Geoscience, 3(2), pp. 139-147, DOI: 10.17014/ijog.3.2.139-147.

Maulana, A., Sufriadin, Sanematsu, K. and Sakakibara, M., (2019) "Study on Sc-bearing Lateritic Ni deposits in Ultramafic Rock from Sulawesi: A New Paradigm in Indonesia Metal Mining Industry", In IOP Conference Series: Materials Science and Engineering, 676(1), pp. 012032, IOP Publishing.

Shaoquan, X. and Suqing, L., (1996) "Review of the extractive metallurgy of scandium in China (1978-1991)", Hydrometallurgy, 42(3), pp.337-343. DOI: 10.1016/0304$386 \mathrm{X}(95) 00086-\mathrm{V}$.

Singhal, Subhash C and Kendall K., (2003) High Temperature Solid Oxide Fuel Cells: Fundamentals, Design, and Applications, UK: Elsevier Publishing Company, pp. 430.

Sunjaya, D., Sahri, A. A. and Widyastuti, M., (2019a) "Potential source of rare earth element (REE) from bauxite laterite in Tayan mining site, West Kalimantan, Indonesia, Yogyakarta", Proceedings Joint Convention Yogyakarta 2019, HAGI - IAGI - IAFMIIATMI (Jcy 2019).

Sunjaya, D., Nugraheni, R. D., Sahri, A.A. Widyastuti, M. and Hindarto, A., (2019b) "Mineral classification of bauxite laterite in Tayan mining site, West Kalimantan, Indonesia, Yogyakarta", Proceedings Joint Convention Yogyakarta 2019, HAGI - IAGI - IAFMI- IATMI (Jcy 2019).

Surata, M., Suksiano, O., Pratomo, M. and Supriyadi, (2010) "Discovery and its genetic relationship of bauxite deposit in Mempawah and Landak regency, West Kalimantan Province", In Proceeding of Kalimantan Coal and Mineral Resources Seminar, pp. 107-116.

Swamidharma, Y. C. A., (2020) "Critical Raw Materials (Personal Perspective in Exploration Activity)", IAGI Webinar. Online.

Valeton, I, (1972) Bauxites: Development in Soil Science, Vol. 1, Elsevier Publishing Company, London, pp. 218.

Vind, J., Malfliet, A., Bonomi, C., Paiste, P., Sajó, I. E., Blanpain, B., Tkaczyk, A. H., Vassiliadou, V. and Panias, D., (2018) "Modes of occurrences of scandium in Greek 
bauxite and bauxite residue", Minerals Engineering, 123, pp. 35-48, DOI: 10.1016/j.mineng.2018.04.025

Walters, A. S., and Lusty, P., (2011) "Rare Earth Elements: British Geological Survey commodity profile", Natural Environment and Research Council, Nottingham.

Wulansari, D., Setijadji, L. D., and Warmada, I. W., (2016) "Karakterisasi kandungan mineral dalam bauksit dengan metode xrd semi-kuantitatif di kawasan tambang tayan, Kalimantan Barat", Proceedings Seminar Nasional Kebumian Ke-9, pp. 612-623.

Zhou, B., Li, Z. and Chen, C., (2017) "Global potential of rare earth resources and rare earth demand from clean technologies", Minerals, $7(11), \quad$ pp. 203. DOI:10.3390/min7110203. 